\title{
Institutional Frameworks for Sustainability? A Comparative Analysis of the Forest Sectors of Russia and the Baltic States
}

\begin{abstract}
After the break-up of the Soviet system, the divergence in forest management among Soviet republics became obvious. While the forest sectors of the Baltic States have been fundamentally changed, Russia has not been able to develop an institutional framework that would fit the prerequisites for social-ecological resilience. It is argued that sustainable development requires institutional frameworks that have the capacity to adapt and learn, and thus to treat policies as experiments that are constantly assessed and readjusted. This, however, requires a participatory approach and in this respect the Baltic States are believed to be on a more promising track. Finally, it is concluded that only to the extent that suitable institutional frameworks will be developed will social-ecological resilience be a significant feature of the natural resources management in the former communist countries.
\end{abstract}

\section{INTRODUCTION}

Together with the other states of the former Soviet Union, Russia possesses an enormous forested area. The Russian federation alone has $23 \%$ of all forests and more than half of all the coniferous forests in the world (1). During the communist era, the forest sector was an important branch of the Soviet economy (2-4). However, after the break-up of the Soviet Union, Russia went through a decade of decreasing productivity, a trend that has only recently been broken (5). In contrast, the Baltic States - also the former Soviet Union republics - showed a more promising economic output from the forest sector and better prospects for sustainability $(6,7)$. How can these differences be explained?

As a result of the dismantling of the Soviet Union, the management of forests and other natural resources was reorganized along with the overall restructuring of society. From the "ruins" of the old system a new society was to be created, something that was expected to be accomplished instantly. In retrospect, it can be concluded that Russia was faced with a challenge that contained three huge sub-tasks to be handled simultaneously: $i$ ) the restructuring of the economy; ii) state-building; and iii) nation-building, i.e. to establish Russia as a nation (8). The details of this transition have been analyzed in many studies and need not be repeated here. However, the third task did not apply to the Baltic States, which had been independent nations before annexed to the Soviet Union after World War II.

Although it might be true that the Russian and Baltic forests constitute a significant resource, this is only part of a large picture. A resource is something that can be considered useful and valuable under the conditions in which it is found (9). However, for a natural resource to be a valuable asset, two other factors are necessary. The first is technology and the second is the institutional structure embedding the resource (10). Technology within forestry, as well as within all other sectors, is defined by the state and the quality of physical capital, and by the human capital that is involved in the activities related to the resource. The structure, usefulness, and appropriateness of technology are closely related to the other general features of a resource, namely, the institutional arrangements. Without adequate institutional arrangements any technology might be completely insignificant (10).

There is no one-to-one relationship between the size of a natural resource and its economic and utility values. The overutilization of natural resources in many developing countries illustrates this fact. Developing countries often possess significant resources, but due to political, organizational and technological factors their resources are not contributing to the well-being of their people, while, at the same time, the significant resource bases might be devastated (11). Only within a framework of institutional arrangements can a forest resource be regarded as an asset in an economic sense and only within a suitable institutional framework can degradation and depletion be prevented.

Institutions are "the rules of the game" (12), and without them no economic or social activity can take place. Institutions are made up of formal as well as informal rules, norms and value systems $(13,14)$. Institutions facilitate the interaction between people and organizations. Hence, systems of rules - well developed and configured - are a basic prerequisite for markets to run smoothly, but they also provide the basic structure that facilitates sustainable resource management (15-17). While the situation in the Russian forest sector still is very problematic, both in terms of economy and ecology, the Baltic States seem to have found ways to establish a better foundation for sustainability in the management of their forests (18).

In this context, two questions can be raised. Firstly, how can the relative success in the forest sector of the Baltic States be explained in comparison with the Russian situation? Secondly, what lessons would this comparison provide us with in relation to the prerequisites for social-ecological resilience, i.e. how social and ecological systems might work in concert?

For purposes of comparison, we have chosen to concentrate on the forest sector. This approach has some obvious methodological advantages. Russia and the Baltic states are rich in forests (19). A significant part of both Russia and the Baltic countries is covered with the boreal forests. More important, however, is the circumstance that, before perestroika, these countries were for more than 40 years part of the same political and economic system (20-22). As a consequence the forest sector was organized in the same, centralized way (23-27). Thus, the forest sectors of Russia and the Baltic states provide an excellent case of "similar-systems design", i.e. the comparison is based on similar cases (28-30). Both areas share the Soviet heritage, among other things they also were integrated in and thus practiced the same type of forest management; and were endowed with the same type of forest resources. This methodology implies that if we find differences in institutional performance (31) these cannot, 
logically, be attributed to the features held by the two cases in common. Hence, it is important to ask what the administrators of forest resources of the Baltic States did that the Russians did not and how these differences could be associated with economic progress and the implications for sustainability.

This article is based on the assumption that the major divergences in functionality of forest sectors can be attributed to the differences in the institutional framework. We will also demonstrate that the prospects for social-ecological resilience, as discussed by Berkes, Folke and others (32) are closely related to the configuration of the institutional framework.

In the following section we provide the evidence that there have been significant differences in performance of the forest sectors among the countries of interest. In our case studies, we discuss to what extent the policy-making process that produced these differences has had different institutional frameworks and decision-making environments. We then present an analysis of how different features of the development can be understood in relation to the notion of sustainable management of natural resources. The article concludes with a discussion of the implications that can be derived from the cases.

\section{RUSSIAN PROBLEMS AND BALTIC RESTRUCTURING}

At the time of the demise of the Socialist era some $90 \%$ of the Eastern European countries' economies relied on the public sector. Together with fundamental changes in the economy, such as the introduction of free competition, and price liberation, changes also encompassed extensive privatization schemes (33). Production can be used as a proxy measure to assess the effects of these policies on the forest sector. From the information provided in Figure 1, it can be concluded that, while Russia has experienced a severe drop in wood production, Estonia has demonstrated a steady increase. The same occurred in Latvia and Lithuania (18). How can these differences be explained?

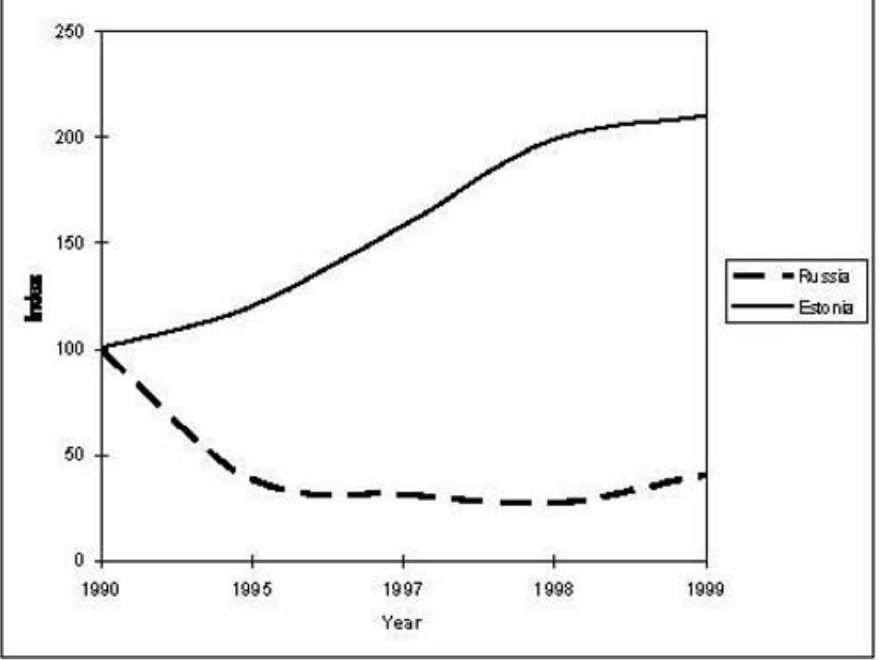

Figure 1. Harvesting of wood in Estonia and Russia 1990-1999. (Source: Kallas (34), and the IIASA Forest Database).

One possible answer to this question is that the rich endowments of forest lands, in combination with a favorable geographic location, has given Estonia and the other Baltic states a competitive advantage. Russia has, however, been forced to struggle with the survival of the forest sector in densely forested areas such as, Tomsk and Krasnoyarsk, which are distant from both western and eastern markets. This explanation is not suf- ficient, however. In fact, also comparable Russian regions such as Arkhangelsk and Karelia, with much better geographic locations, show the same negative trend as the rest of Russia (35, 36). For an institutional analysis of the current situation in the Russian forest sector see Carlsson et al. (37).

\section{RUSSIAN PROBLEMS}

Institutional performance in the forest sector is not only a matter of wood production. Natural resource management also includes means and methods to prevent devastation or depletion of the resource base. To prevent this, rules and regulations must be developed and, more importantly, stakeholders must be convinced that these apply equally to all and that they, in fact, can be implemented. This is a matter of trust and legitimacy. Obviously, it is not enough to adopt environmental laws without successful implementation. Well-designed institutional arrangements, understood as rules in use, also enable legal measures to be taken against infringements. Considering this context, the situation in Russia is very problematic (38). In fact, it is only because of the relatively low levels of production that the environmental situation is not worse. The current state in the Russian forest sector can be summarized as follows:

- Despite abundant forest resources there is a shortage of timber for the large industries, while at the same time the internal and external demand for wood is weak;

- There is a lack of congruence between central and regional levels of decision-making related to the forest sector;

- The forest management system is poorly funded, e.g. forest fire protection and regeneration programs are severely underfinanced;

- Even though new rules of forest management and protection were enacted, there is a general lack of mechanisms for their implementation;

- The timber price is artificially low, transportation fees and taxes are immense, internal and foreign trade is undeveloped;

- Corruption and criminalization of the sector is significant;

- Degradation and devastation of forest resources continue;

- A significant number of firms run at a loss;

- An increase in the practice of barter, rent seeking and a widespread custom of negotiating for privileges prevent the firms from acting as commercial actors and thus promoting the market system $(39,41)$.

Additionally, in Russia no forest land has been privatised, and to a great extent different officials from the Soviet era have succeeded in keeping or gaining leading positions within the forest industry, management, and trade (42). The basic features of the Soviet forest management system were retained-those in a position to change policy are reluctant to do so due to hidden personal objectives. The Russian forest sector remains based on old Soviet features, which are expressed in a strong tradition of decision-making based on personal relations, in the negotiations for subsides and tax relief and other means to avoid real restructuring of the sector $(37,43)$.

\section{Baltic Restructuring through Stakeholder Participation}

In what respect does the restructuring of the Baltic forest sector differ from that of Russia. Although Russia became a cornerstone of the Soviet Union immediately after the Russian revolution, Estonia, Latvia and Lithuania were annexed to the Soviet Union as a result of military action during World War II after several decades of independence. Thus, the disintegration of the Soviet Union meant that the Baltic States regained their inde- 
pendence. This historical circumstance from the very beginning of the transition period, made the legitimacy of the new Baltic regimes grater than in Russia. This difference also made it possible to re-establish private ownership through the implementation of extensive privatization schemes. These reforms have been generally accepted and have affected agricultural as well as forest sectors. The process is almost completed (45). Similar development has not yet taken place in Russia.

In the Baltic States, the restructuring of the forest sector was to a large extent based on a participatory approach. The main feature of this approach was broad representation of a variety of stakeholders such as bureaucrats, politicians, the private sector, and environmental NGOs in the policy process, thus, giving the restructuring a degree of legitimacy $(17,34)$. Although the development in the forest sectors of the Baltic States is uneven,

Table 1. Comparison between changes in the forest sector of the Baltic States and Russia since 1991.

\begin{tabular}{|c|c|}
\hline Baltic States & Russia \\
\hline $\begin{array}{l}\text { The integrated forest-to-industry } \\
\text { system has been dismantled }\end{array}$ & $\begin{array}{l}\text { The integrated forest-to-industry } \\
\text { system has been dismantled }\end{array}$ \\
\hline $\begin{array}{l}\text { Massive privatization of logging } \\
\text { companies and industries }\end{array}$ & $\begin{array}{l}\text { Massive privatization of logging } \\
\text { companies and industries }\end{array}$ \\
\hline $\begin{array}{l}\text { Substantial privatization of forestland } \\
\text { (in Estonia } 52 \% \text { privately owned, } \\
48 \% \text { public, Latvia - } 45 \% / 51.1 \% \text { and } \\
\text { in Lithuania - } 50 \% / 50 \% \text { ) }\end{array}$ & $\begin{array}{l}\text { No privatization of forestland has } \\
\text { been done }(\approx 100 \% \text { publicly owned })\end{array}$ \\
\hline $\begin{array}{l}\text { New national forest codes have } \\
\text { been enacted }\end{array}$ & $\begin{array}{l}\text { New national forest code was en- } \\
\text { acted in } 1993 \text { (and in 1997) }\end{array}$ \\
\hline $\begin{array}{l}\text { Change of leadership in forestry } \\
\text { departments }\end{array}$ & $\begin{array}{l}\text { No substantial change of leader- } \\
\text { ship of the central forestry authori- } \\
\text { ties }\end{array}$ \\
\hline $\begin{array}{l}\text { Forest management and control } \\
\text { functions were separated and pres- } \\
\text { ently are under responsibility of dif- } \\
\text { ferent institutions }\end{array}$ & $\begin{array}{l}\text { No similar change has taken place } \\
\text { in Russia }\end{array}$ \\
\hline $\begin{array}{l}\text { In Latvia and Lithuania forestry ad- } \\
\text { visory boards to the ministers in } \\
\text { charge of forest sector were estab- } \\
\text { lished in order to make top-level for- } \\
\text { est management decision-making } \\
\text { democratic and more transparent }\end{array}$ & $\begin{array}{l}\text { No such activity has taken place in } \\
\text { Russia. } \\
\text { Forest management is organized } \\
\text { virtually the same way and is as } \\
\text { centralized as before }\end{array}$ \\
\hline $\begin{array}{l}\text { Open tendering privatization of } \\
\text { timber processing industry with an } \\
\text { orientation toward strategic inves- } \\
\text { tors independently if the enterpris- } \\
\text { es were acquired by local or for- } \\
\text { eign capital }\end{array}$ & $\begin{array}{l}\text { Privatization has been a business } \\
\text { for insiders, typically former man- } \\
\text { aging directors who took over } \\
\text { shares that had been distributed } \\
\text { among employees }\end{array}$ \\
\hline $\begin{array}{l}\text { Due to out-dated technological and } \\
\text { management capacity, many firms } \\
\text { were forced into bankruptcy. Ap- } \\
\text { proximately half of the companies, } \\
\text { mostly the ones that were bought } \\
\text { up by entrepreneurs from abroad, } \\
\text { have been reconstructed and are } \\
\text { still in business }\end{array}$ & $\begin{array}{l}\text { Due to the lack of efficient bank- } \\
\text { ruptcy and arbitrage systems, invi- } \\
\text { able firms continue to operate. The } \\
\text { restructuring of the forest firms is } \\
\text { insignificant }\end{array}$ \\
\hline $\begin{array}{l}\text { The split between the State and the } \\
\text { enterprises tore apart the Soviet } \\
\text { era network relations that had been } \\
\text { established between the different } \\
\text { Government offices. Subsidies dis- } \\
\text { appeared and private industries } \\
\text { were left without any major public } \\
\text { support }\end{array}$ & $\begin{array}{l}\text { The very existence of most enter- } \\
\text { prises in the Russian forest sector } \\
\text { is dependent on old relations, wide- } \\
\text { spread systems of tax relief, and } \\
\text { other privileges. Barter trade is a } \\
\text { common practice and public au- } \\
\text { thorities are heavily involved }\end{array}$ \\
\hline $\begin{array}{l}\text { The introduction of barrier-free } \\
\text { trade, the abolishment of State sub- } \\
\text { sidies, the frequent privatization of } \\
\text { industries to foreign strategic invest- } \\
\text { ment, has been achieved with the } \\
\text { support from the electorate }\end{array}$ & $\begin{array}{l}\text { The majority of the Russian elector- } \\
\text { ate support political parties which in } \\
\text { their agendas oppose such policies }\end{array}$ \\
\hline $\begin{array}{l}\text { Generally, the forest sector is char- } \\
\text { acterized by law and order. Authori- } \\
\text { ties possess means for implemen- } \\
\text { tation and enforcement of rules and } \\
\text { although violations exist, measures } \\
\text { are taken against infringements }\end{array}$ & $\begin{array}{l}\text { Criminalization and corruption con- } \\
\text { tinues. Property rights are ill de- } \\
\text { fined, the forest law collides with } \\
\text { the constitution, environmental law } \\
\text { collides with other regulations }\end{array}$ \\
\hline
\end{tabular}

${ }^{1}$ The list is based on our own research (publications are listed in the reference list) and a number of secondary sources, in particular Kallas, (35). and, there remain differences in the extent to which full participation has been achieved, the fundamental nature of the process is quite different from the top-down hierarchical approach that has been practiced in Russia.

Table 1 summarizes the main differences in the restructuring of the forest sectors in Russia and those of the Baltic States. The political and economic changes in the two countries have affected the forest sectors in different ways.

In the attempt to generalize the logic behind the observed differences, the Baltic changes appear to have been governed by the substantial efforts to reorganize and renew institutions, while the Russian situation reflects a desire to preserve old structures. Why is the situation so different and how can it the fact that the Baltic decision-makers have been able to restructure the forest sector while the Russians have failed so far be explained?

\section{INSTITUTIONAL PERFORMANCE AND SUSTAINABILITY}

It is likely that the policy decisions made, for example in the Estonian forest sector, to a large extent were successful because they supported informal but important features of the institutional framework. These features can be understood in terms of trust, aptitude for public participation, legitimacy, acknowledgement of property rights, and the existence of norms and conventions that foster law and order (46). The implicit argument is that the lack of similar qualities explains the problems that still seem to dominate the Russian forest sector.

There is overwhelming evidence for such conclusions. The relatively high level of distrust and corruption in Russia (and many other previously communist countries) is well documented. In these studies, the Baltic States show more positive, picture (47-52). The roots of such differences, e.g. historical development and the assumed high level of legitimacy of political authority in the Baltic states in association with the re-gaining of independence, have already been mentioned.

However, the differences might teach us yet another lesson that relates to the prospects for sustainability. Typically forest ecosystems are complex and dynamic. They have therefore proven difficult to manage using modern systems based on licensing, allocation of catchment quotas, calculation of annual yields, and the management of single species. This type of management was an integrated feature of the planning system in the Soviet Union and is still believed to be fundamental within the Russian forest sector. The same management problems are also found for many types of natural resources that societies try to manage $(53,54)$.

The political structure of the Baltic States can be characterized by efforts to decentralize management of forest resources. This is clearly expressed by $i$ ) introducing private forest ownership; ii) allowing the private sector on a commercial basis to participate in management of state forest; iii) separating control and management functions in state forestry, which in the Soviet system were under the same institutions; $i v$ ) forcing timber processing industries to purchase wood on a competitive basis. These features of a new system make administration of forest resources complex and dynamic, which in the shift from a previously hierarchical centralized planning economy constitute a great contrast.

While ecosystems obviously are dynamic, our management systems are strikingly linear, meaning that we tend to apply procedures for calculating and "harvesting" maximum amounts of resource units (fish, animals, trees, etc.) with the primary aim to uphold maximum yield rather than to sustain the ecosystems themselves (55). The basic challenge is to develop institutional 
systems able to adapt to the dynamics of the ecosystem under focus.

One of the most important concepts for resolving this challenge is that of resilience. Resilience is the ability of a resource system to survive disturbances and its capacity to undergo stress and yet to recover, or more exactly, "the ability of [the] system to maintain its structure and patterns of behavior in the face of disturbance" (56). Conventional resource management policies, such as forest management in the former Soviet Union, emphasize stability through equilibrium, low variability, resistance to and absorption of change. In an analysis of the Russian forest sector, the World Bank concluded that the forest management practices of the former Soviet Union left the new Russian Federation with "a legacy of overuse" (2).

Contrary to the conventional resource management approach, management policies based on the ideas of resilience emphasize "events far from the balanced position, high variability, and adaptation to change" (56). These thoughts are grounded in complex systems theory, which provides an alternative to the "perspective of a world in steady state or near-equilibrium that has dominated resource and environmental science and policy" (58). Intuitively, it can be understood that this approach conflicts with a forest management practice that is exercised within political administrative hierarchies and with a major concern to supply industry with wood.

A rather recent but very vital line of research has explicitly focused on the relationship between social and ecological systems. Thus, the concept of resilience has been refined so that it captures the interplay between those types of systems. These ideas have been brought to the public in two influential volumes $(32,58)$. Social-ecological resilience has three distinguishing features: $i$ ) the amount of change the system can undergo and still retain the same controls on function and structure; ii) the degree to which the system is capable of self-organization; and iii) the ability to build and increase the capacity for learning and adaptation (http://www.resalliance.org/ev.php). By adopting this attitude, for example, the forests of Russia cannot be separated from the social structures that affect them; they should be understood and analyzed as a unity.

From this it follows that sustainability presumes that social systems, institutions as well as management systems, must have the capacity to respond to changes in the ecosystems, to be adaptive. Following The World Conservation Union we understand adaptive management as "an approach based on the recognition that the management of natural resources is always experimental, that we can learn from implemented activities, and that [Natural Resources Management] can be improved on the basis of what has been learned" (59).

What has been indicated in this article is that, while the forest sectors of the Baltic states have been fundamentally changed, Russia has not been able to develop an institutional framework that would fit the prerequisites for social-ecological resilience. In fact, it can be concluded that in Russia, the old institutions have shown a significant resilience, they have succeeded in adapting to new circumstances and have retained their basic features. Thus, it can be assumed that the Baltic restructuring, with its incorporation of different interest groups and an explicit move towards transparency in management of natural resources, provides a better foundation for social-ecological resilience.

\section{CONCLUSION}

As discussed by many scholars, every management system is incorporated into a wider institutional framework $(16,17,60)$. Consequently, all forest management systems are composed of a hierarchy of units and of a rich web of rules and regulations (formal as well as informal) that ultimately determine what can be done or not at the national, regional and local levels. Thus, management decisions on an operational level depend on collective decisions taken on municipality or county levels, which in turn are subordinated by central political-administrative decisions as well as constitutional considerations. This has a number of implications for public administration and management. How should a Russian (or Estonian, Latvian or Lithuanian) forest management system be tailored as to make it possible to span the multiple levels of institutions and facilitate sustainable management of forest resources? One way of achieving adaptive capacity is to develop systems that are based on the ideas of co-management, i.e. systems that consist of a set of mutual agreements between different stakeholders that may represent a variety of actors such as local users, scientific experts, and public authorities $(61,62)$.

Co-management systems have proven positive in many respects, especially for enhancing adaptive capacity $(60,63,64)$. One major advantage is that, due to the incorporation of various stakeholders and thus qualifications, as was the case in the Baltic states, well functioning co-management systems establish cross-scale linkages across different levels of administration as well as between geographically separated areas, smaller and bigger management units, and so forth $(62,65)$. A successful establishment of these linkages has proven important when managing complex and dynamic systems such as forests.

Only to the extent that suitable institutional frameworks are developed will social-ecological resilience be a significant feature of the natural resources management in the former communist countries. A sustainable development requires institutional frameworks that have the capacity to adapt and learn, and thus to treat policies as experiments that are constantly assessed and readjusted. This, however, requires a participatory approach and in this respect the Baltic States seem to be on a more promising track.

\section{References and Notes}

1. Nilsson, S. and Shvidenko, A. 1997. The Russian Forest Sector; A Position Paper for The World Commission on Forests and Sustainable Development. Paper presented at the WCFSD Meeting in St. Petersburg, Russia, 23-24 September 1997. URL: http://iisd1.iisd.ca/wcfsd/russia.htm.)

2. The World Bank. 1997. Russia; Forest Policy during Transition, A World Bank Country Study, The World Bank, Washington, DC, XIV, 279 pp.

. Kairiukstis, L. (ed.). 1962. Forests of Lithuanian SSR., Valstybine politines ir mokslines literaturos leidykla, Vilnius, p. 268. (In Lithuanian).

4. Morkevicius, A. 1985. Lietuvos TRS liaudies ukio aprupinimas mediena ir kompleksinis jos panaudojimas (Timber Supply and Utilization in Lithuanian SSR). LIMTI, Vilnius, p. 48. (In Lithuanian)

5. FAO 2002. Forest statistics,

(http://apps.fao.org/lim500/nph-wrap.pl?Forestry.Primary\&Domain=SUA\&servlet=1)

6. Centre of Forest Economics. 2002. Lithuanian Statistical Yearbook of Forestry. MEC, Vilnius. $112 \mathrm{pp}$.

7. Ministry of Agriculture of the Republic of Latvia. 2002. Forest Sector in Latvia, p. 31.

8. Breslauer, G.W. 1995. Aid to Russia: What Difference Can Western Policy Make. In: The New Russia; Troubled Transformation. Lapidus, G.W. (ed.), Westview Press, Boulder, San Francisco, Oxford, pp. 223-244.

9. Randall, A. 1987. Resource Economics. John Wiley and Son, New York.

10. Kant, S. and Nautiyal, J.C. 1992. Economic Theory of Commons: Revisited. Faculty of Forestry, University of Toronto, Canada.

11. Hulme, D. and Murphree, M. 2001. Community conservation as policy: Promise and performance. In : African Wildlife \& Livelihoods. The Promise and Performance of Community Conservation. Hulme, D. and Murphree, M. (eds). James Currey Ltd Oxford. Pp. 280-297.

12. North, D. 1990. Institutions, Institutional Change and Economic Performance. Cambridge University Press, Cambridge. 152 pp.

13. Mayers, J., and Bass, S. 1998. The role of policy and institutions. In: Tropical Rain Forest: A Wider Perspective. Goldsmith. F.B. (ed.). Chapman and Hall, London pp. 269-302.

14. Larsen, H.O., Olsen, C.S. and Boon, T.E. 2000. The non-timber forest policy process in Nepal: actors, objectives and power. Forest Policy and Economics 1, 267-281.

15. Milgrom, P., North, D. and Weingast, B.R. 1990. The Role of Institutions in the Revival of Trade: The Law Merchant, Private Judges, and the Champange Fairs, Economics and Politics 2, 1-23.

16. Ostrom, E. 1990. Governing the Commons. Cambridge University Press, New York. 280 pp.

17. Imperial, M.T. 1999. Institutional analysis and ecosystem-based management: The institutional analysis and development framework. Environ. Manage. 24, 449-465.

18. Lazdinis, M. 2002. Facilitating sustainable forest development: Comparative analy- 
sis of post-soviet forest politics in the Baltic states. PhD Thesis, Southern Illinois University, Carbondale, IL, USA, p. 388

19. FAO. 2001. State of the World's Forests 2001. Food and Agriculture Organization of the United Nations. Rome, $200 \mathrm{pp}$

20. Kaminski, A.Z. 1992. An Institutional Theory of Communist Regimes, ICS Press, San Francisco. 414 pp

21. Shen, R. 1994. Restructuring the Baltic Economies: Disengaging Fifty Years of In tegration with the USSR. Praeger, London, $241 \mathrm{pp}$

22. Gardner, H.S. 1997. Comparative Economic Systems. The Dryden Press, XXI, 761 pp

23. Blandon, P. 1983. Soviet Forest Industries. Westview Press, Boulder, 290 pp.

24. Litvin, V. 1987. The Soviet Agro-Industrial Complex: Westview Press. Boulder, $\mathrm{CO}, 161 \mathrm{pp}$

25. Barr, B and Braden. K.E. 1988. The Disappearing Russian Forest. Rowman \& Littlefield, London, $252 \mathrm{pp}$

26. Petrov, A.P. 1989. Management and organization of forest industries and forestry in the USSR. In: The H.R. MacMillan Lectureship in Forestry. Faculty of Forestry, University of British Columbia, Vancouver, $19 \mathrm{pp}$

27. UNECE/FAO. 1989. Outlook for the Forest and Forest Products Sector of the USSR United Nations Economic Commission for Europe and Food and Agriculture Organization of the United Nations, NY, 59 pp.

28. Przworski, A. and Teune, H. 1970. The Logic of Comparative Social Inquiry. John Wiley \& Sons, New York, $153 \mathrm{pp}$

29. Meckstroth, T. W. 1975. "Most different systems" and "Most similar systems": A study in the logic of comparative inquiry. Comparative Political Studies 8, 132-157.

30. Peters, B.G. 1998. Comp. Politics: Theory and Methods. New York University Press, New York. 262 pp

31. The concept of institutional performance is discussed in Ostrom, E., Schroeder, L. and Wynne, S. 1993. Institutional Incentives and Sustainable Development: Infrastructure Policies in Perspective. Westview Press, Boulder. $266 \mathrm{pp}$

32. Berkes, F. and Folke, C. 1998. Linking Social and Ecological Systems, Managemen Practices and Social Mechanisms for Building Resilience. Cambridge University Press, New York, $459 \mathrm{pp}$

33. Major, I. 1993. Privatization in Eastern Europe: a Critical Approach. Edward Elgar Publishing Ltd, London, $164 \mathrm{pp}$.

34. Kallas, A. 2000. The Estonian Forest Sector in Transition: Institutions at Work. IIASA, Interim Report (IR-00-073), Laxenburg, Austria, 27 pp.

35. Carlsson, L., Lundgren, N-G., Olsson, M-O and Varakin, M. 2000. Institutions and the Emergence of Markets, Transition in the Arkhangelsk Forest Sector. IIASA, Interim report (IR-99-021) Laxenburg, Austria, 95 pp.

36. Piipponen, M. 1999. Transition in the forest sector of Karelia. Fennia 177 (2), 185 233

37. Carlsson, L., Lundgren, N-G. and Olsson, M-O. 2001. The Russian Detour: Rea Transition in a Virtual Economy? Europe-Asia Studies. 5366, 841-867

38. Nysten-Haarala, S. 2001. Russian Law in Transition: Law and Institutional Change. Kikimora Publications, Helsinki. 289 pp.

39. Carlsson, L. 2000. Towards a sustainable Russian forest sector. Nat. Res. Forum 24, 31-37.

40. The term rent-seeking refers to various ways by which individuals, or groups, by virtue of their position strive for special advantages at the cost of other actors. The list of conclusions has been presented and discussed in relation to a number of policy exercises that have been conducted in Russia (42). Although production figures have increased during the past couple of years no significant restructuring of the forest sector has been done yet.

41. Olsson, M-O. 2001. Participatory Forest Policy Development - Experiences from a IIASA Policy Exercise in Tomsk, Russia. IIASA, Interim Report IR-01-061. Laxenburg, Austria, $69 \mathrm{pp}$.

42. Lehmbruch, B. 1999. Fragmented clientelism: The transformation of sectoral economic governance in the Russian timber industry. In: Anatomy of the 1998 Russian Crisis. Tikhomirov, V. (ed.). Contemporary Europe Research Centre, University of Melbourne, Carlton, pp. 238-258.

43. Gaddy, C. and. Ickes, B. 1998. Russia's Virtual Economy. Foreign Affairs 5, 5367

44. This is fairly well documented. Throughout the past transition period, for example The New Russian Barometer has provided data on how the Russian people look upon different aspects of the development. Similar studies have been conducted in the other east European countries.

45. Rose, R., Mishler, W. and Haerpfer, C. 1998. Democracy and its Alternatives. Polity Press, Oxford. $270 \mathrm{pp}$.

46. Le Master, D. 2003. Institutional framework necessary for forest management in a market economy. In: Experiences with New Forest and Environmental Laws in European Countries with Economies in Transition. Le Master, D. Herbst, P. and Schmithusen, F. (eds). Swiss Federal Institute of Technology, Zurich, pp. 1-10.

47. Mishler, W. and Rose, R. 1998. Trust in Untrustworthy Institutions: Culture and In stitutional Performance in Post-Communist Societies. Studies in Public Policy No 310, 33

48. Fell, A. 1999. On the Establishment of Trust in the Russian Forest Sector. IIASA, Interim Report (IR-99-054), Laxenburg, Austria. $31 \mathrm{pp}$.

49. The World Bank 2000. Anticorruption in Transition A Contribution to the Policy DebateThe World Bank, Washington DC.

(http://www.wds.worldbank.org/servlet/WDS_IBank_Servlet?pcont=details\&eid=0 $00094946 \quad 2002-0420$.)

50. The World Bank. 2002. Transition - The First Ten Years Analysis and Lessons for Eastern Europé and the Former Soviet Union. The World Bank, Washington DC. http://www-wds.worldbank.org/ 2002-04-20.

51. The World Bank 2002. Corruption index 1996-97.

http://wbln0018.worldbank.org/psd/compete.nsf/d87a3cd1 dcdb9743852564900 $067444 \mathrm{f}$

52. Transparency International 2002. Corruption Index. http://www.transparency.org/cpi/2001/cpi2001.htm

53. Wilson, J.A., Acheson, J.M., Metcalfe, M. and Klebam P. 1994. Chaos, Complexity and Community Management of Fisheries. Marine Policy 18, 291-305.

54. Gunderson, L.H., Holling, C.S. and Light, S. (eds). 1995. Barriers and Bridges, to the Renewal of Ecosystems and Institutions. Columbia University Press, New York, $593 \mathrm{pp}$

55. Getz, W.M. and Haight, R.G. 1989. Population Harvesting: Demographic Models of Fish, Forest, and Animal Resources. Princeton University Press, Princeton, $391 \mathrm{pp}$

56. Holling, C.S. 1986. The resilience of terrestrial ecosystems: local surprise and global change. In: Sustainable Development of the Biosphere. Clark, W.C. and Munn, R.E. (eds). Cambridge University Press, Cambridge, pp. 292-317.

57. Folke, C. et al. 2002. Resilience and Sustainable Development, Building Adaptive Capacity in a World of Transformations. Scientific background paper on Resilience for The World Summit on Sustainable Development, a report for The Swedish Envi- den.$$
\text { den. }
$$
tems, Building Resilience for Complexity and Change. Cambridge University Press, New York, $393 \mathrm{pp}$

59. Borrini-Feyerabend, G. Farvar, G.M., Nguinguiri, J.C. and Ndangang, V. 2000. Comanagement of Natural Resources: Organising Negotiation and Learning by Doing. Kasparek Verlag, Heidelberg.

60. Schmithüsen, F. 2000. The expanding framework of law and public policies governing sustainable uses and management in European forests. In: IUFRO World Series Volume 10 - Forging a New Framework for Sustainable Forestry: Recent Developments in European Forest Law. Schmithüsen, F. Herbst, P. and Le Master, D. (eds). IUFRO, Zurich, pp. 1-27

61. Cash, D.W. and Moser, S.C. 2000. Linking global and local scales: Designing dynamic assessment and management processes. Global Environmental Change 10 (2), $109-120$

62. Carlsson, L. and Berkes, F. 2003. Co-management Across Levels of Organization: Concepts and Methodological Implications. Lead paper presented at the Resilience panel at the Regional Workshop of International Association for the Study of Common Property (IASCP), "Politics of the Commons: Articulating Development and Strengthening Local Practices", Chiang Mai, Thailand, July 11-14, 2003.

63. Pinkerton, E. (ed.). 1989. Co-operative Management of Local Fisheries. University of British Columbia Press, Vancouver. 299 pp.

64. Berkes, F. George, P and Preston, R. 1991. Co-Management: The Evolution of the Theory and Practice of Joint Administration of Living Resources. Alternatives 18 (2), 1218.

65. Berkes, F. 2002. Cross-scale institutional linkages: perspective from the bottom up. In: The Drama of the Commons. Ostrom, E., Dietz, T., Dolšak, N., Stern, P.C., Stonich, S. and Weber, E.U. (eds). National Academy Press, Washington DC, pp 293-321

Lars Carlsson is a professor at Luleå University of Technology. His main research interests are natural resources management, implementation, policy making and institutional analysis. He has been working as a visiting faculty scholar at the workshop in Political Theory and Policy Analysis, Indiana University where he conducted research about common-pool resources. In 1997, Carlsson became a visiting scientist within The Sustainable Boreal Forest Resources Project at the International Institute for Applied Systems Analysis (IIASA). His IIASA research focused on institutional aspects of the Russian forest sector. His address: Department of Business Administration and Social Science, Division of Social Sciences, Lulea University of Technology, SE-971 87 Lulea, Sweden. lars.carlsson@ies.luth.se

Marius Lazdinis started his career at the Ministry of Environment where he was responsible for international cooperation in forest sector. He completed his PhD at Southern Illinois University at Carbondale, USA. He also started a PhD program at the Swedish University of Agricultural Sciences, the title of his work is "Two-dimensional Gap Analysis as a Tool for Sustainable Forest Development". Dr. Lazdinis is currently working at the Faculty of Public Management, Law University of Lithuania. His main interest is research on administration of forest resources, i.e. viewing management of forest resources as a national programme and learning about successes and failures in implementation of such programs. His address: Faculty of Public Management, Law University of Lithuania, \#310, Ateities 20, Vilnius, LT-08303, Lithuania. marius@Itu.It 